\title{
Translation and the Messiah of Language
}

\author{
Seyed Saeed Habibi \\ Department of Translation Studies, University of Applied Science and Technology, Karaj, Iran
}

Received: 18-02-2015

doi:10.7575/aiac.ijclts.v.3n.2p.54
Accepted: 27-03- 2015

Published: 01-04- 2015

URL: http://dx.doi.org/10.7575/aiac.ijclts.v.3n.2p.54

\begin{abstract}
By adopting a different outlook, the present study endeavors to explain Walter Benjamin's The Translator's Task as an attempt to introduce new dimensions to translation studies. To do so, first the intention behind the creation of The Translator's Task was explained through studying key elements proposed in The Translator's Task and searching for instances of these significant factors. It was concluded that The Translator's Task is a reply to the indeterminist nature of languages in the field of translation. Secondly, a translation model based on The Translator's Task was provided and explained. The model used target language lexicon and source language syntax to fully accommodate what was proposed in The Translator's Task. This model was used to produce a sample translation from English to Persian, which was later compared with a published translation. In order to determine the quality of translation, level of determinacy by the ST was assigned as a criterion. To achieve this, each TT was compared with the ST through a back-translation bottom-up analysis and each unit of translation was later categorized as $D$ - determined and positive - or $U-$ undetermined and negative. Finally, the results highlighted the high levels of determinacy by the ST in the sample translation based on the provided model. The published translation, which was a domesticated one, showed lower levels of determinacy by the ST as these kinds of translations are mainly based on the interpretations of the ST.
\end{abstract}

Keywords: Walter Benjamin, The Translator's Task, pure language, radical literalism

\section{Introduction}

The word 'messiah', strange as it may sound upon hearing, has been far more influential than every individual human being can think of. Having transcended itself from a mere word to a belief, if say not a conviction, the idea of a messiah is deeply rooted in the heart and mind of many humans. It has even, not surprisingly, found its way to translation studies and become a central theme in the work of Walter Benjamin (1923/2012), The Translator's Task. Although among translators and in the publishing atmosphere, naturalism is considered by far a very common and popular technique, Benjamin's modernist debate in The Translator's Task concludes the awkward 'interlinear literalism' as a reach out to release the 'pure language', and introduces the 'indeterminacy of translation' as a 'virtue' of translation (Pym, 2014: 95). But why does Benjamin have to adopt such a radical approach toward translation? What is the rationale behind The Translator's Task? Is it possible to produce a translation model based on The Translator's Task? And if so, what are the applications and merits of such a model compared with other translation models?

The present paper attempts to answer some of the above questions through examining key concepts posited in Benjamin's The Translator's Task. It also endeavors to provide a practical model of translation based on The Translator's Task and produce a sample translation of a short given text. This will be further accompanied by a comparison of the produced sample translation with a published domesticated one in terms of the degree of determinacy of the two translated texts by the ST. The discussion also touches upon the idea of naturalism, the illusion of equivalence, and literalism in order to redefine the phenomenon of translation and distinguish it from authorship and other written products such as free translation, adaptation, recreation and translocation.

\section{Understanding 'The Translator's Task'}

\subsection{The Rationale behind 'The Translator's Task'}

In order to understand why Benjamin wrote The Translator's Task the way he wrote it, one should understand the ground on which the work is formulated. Affected by Frankfurt School and Marxist belief and based on Kabbalistic knowledge, Benjamin assumes the existence of a language before the Fall, by which God communicated with Adam and Eve in the heaven. According to Benjamin, in this language the 'intended object' and the 'mode of intention' were the same. This language is described as a 'vessel' by Benjamin, but after what happened in the tower of Babel, the 'vessel' broke and every 'fragments' of this 'broken vessel' became indeterminate individual languages, hence creating a 'kinship of languages' as all of them are the 'fragments of a broken vessel'. The famous example of bread - brot in German and pain in French - is then provided to illustrate the difference between 'intended object' and 'mode of intention'. Though both words in German and French refer to the same object, their modes of intention is different from each other. In Benjamin's attitude, this is not a shortcoming, rather an opportunity for the translational action to bring 
these conflicting forces together to create a more complete 'mode of intention', which is only achievable through radical literalism.

Benjamin postulates 'literalism, especially in syntax' as a technique to release 'pure language' in translation and a method to bring the two different 'modes of intentions' together to coexist. Yet, he himself failed to provide an example as the manifestation of his proposed theory in practice. Sanders (2003) explains this lack of practical example in terms of Benjamin being under the influence of Frankfurt School of thought, the fact that theory overshadows practicality from this perspective, and also the very idealistic nature of Benjamin's thoughts that make any manifestations whatsoever impossible. But why should Benjamin focus so emphatically on the notorious technique of radical literalism?

The Translator's Task can be considered as a reply to and reasoning for the indeterminist nature of languages; i.e. one cannot be completely sure about the existence of an equal value among signifiers between two given languages. The situation can even become more complex as variables like individuality and eccentricity are introduced, making it possible to assume that one cannot be completely sure about the fixed relationship between signified and signifier in one particular language. The aforementioned debate dates back as early as Plato and to one of his dialogues entitled Cratylus in which Socrates is asked by two man, Hermogenes and Cratylus, about the relationship between the names of the objects and the objects themselves. The idea highlights two kinds of relationship: a determinist relationship, as in the case of onomatopoeic words that are determined naturally, or an indeterminist relationship in which the object and its name are arbitrarily related (Pym, 2014: 91). This ancient debate is perused in modern times in numerous works and perhaps the most famous one is what postulated by the Swiss linguist Ferdinand de Saussure (1916/1974) as 'signified' and 'signifier' and marked the beginning of Structuralism in linguistics. The notion in question evolved from a mere 'name and object' to 'word and concept' in the work of deconstructionist Jacques Derrida (1999/2012). The same idea exists in Benjamin's The Translator's Task as 'intended object' and 'mode of intention'.

Unlike The Translator's Task, all the works regarding the relationship between word and meaning are of descriptive nature. These descriptive works in the second period of the history of translation theory, designated as 'Communicative Stage' by Peter Newmark (2009), led to the formulation of equivalence and a somehow emphatic focus on naturalism to date. Linguists such as Viney and Darbelnet (1958/1995) and Seleskovitch and Lederer (1984) were virtually in search of equal values between languages. Though strongly questioned by some scholars throughout the history of translation theory (Schleiermacher, 1813/2012; Benjamin, 1923/2012; Steiner, 1975; Venuti, 1995; Sturrock, 2010), the naturalist attitude toward translation has dominated the field and entitled itself as good and literalism as awkward and bad. The problem here is that describing the situation and proposing equivalence and thus naturalism as a better way of translating are just a deviation not to answer the proposed question in the very first place.

What is special about The Translator's Task is its explanatory nature since it tries to explain the uncertainty that exists in determining the meaning relationships, thus shifting this translational shortcoming to a merit. Whereas much has been described about the state of the affair over the past centuries, as early as 1923, Benyamin attempted to explain why this uncertainty exists. Once there existed an absolutely determinist language in which signified and signifiers were the same. But after the Fall, that pure language broke and every piece became a language itself. One might argue that Benjamin's idea of pure language is quite religious and based on Jewish teachings and philosophy and therefore easily reject it by exclaiming not to believe in Judaism, and it is quite true, but let us consider what Benjamin proposes as a source, a source form which all languages are derived. From this perspective, pure language appears to be more similar to the idea of proto-language in linguistics. Linguist George Yule (2014) maintains 'Proto-Indo-European' language as the 'great-great-grandmother' of all the languages on the face of the earth. Benjamin tries to explain that languages are pieces of the source, therefore they cannot be equal to each other and that is the reason behind language indeterminacy. Yet, if we put languages together through radical literalism, they can complete each other and form a larger picture, a larger piece that sheds light on the nature of the source, the pure language, which is absolutely determined. Perhaps this outlook on language is one of the reasons why his work is considered to be seminal.

\subsection{A Model of Translation Based on 'The Translator's Task'}

Slavoj Žižek, the contemporary Slovene philosopher and cultural critic, emphasizes on changing the way a subjectmatter is perceived and questions if it remains the same. Let us change the way we perceive The Translator's Task from a mere philosophical work to a model for translation and examine key elements proposed by Benjamin and try to find real instances of those major elements.

As discussed before, the idea of a 'pure language' can be considered as a source from which all languages are derived. From this perspective, we have come to know that contemporary languages are the offspring of 'Proto-Indo-European' language. This proto-language used to accommodate the needs of our ancestors' very simple and primitive life. The adjectives 'simple' and 'primitive' can be indicative of the high levels of determinacy in the nature of this protolanguage, meaning that the least complicated life necessitates a basic language that creates the minimum of interpretation and thus high levels of determinacy. Likewise, in Benjamin's 'pure language', the 'intended object' and 'mode of intention' are the same and requires no interpretations, which creates an absolute determine language. Similarly, the notion of 'kinship of languages' can be described as all languages are the 'broken' members of a bigger family, or in Benjamin's terminology, a 'vessel', and hence related to each other. 
The story of the tower of Babel can reflect the story of human perfection, though ironical as in the former, it led to failure, but in the latter it seems it will end in victory, of course hopefully. But the past tense used for the tower of Babel indicates that the story is finished and the ending is clear. However, no one knows how the story of human perfection will end. Perhaps, and despite our will, there also lies a tragic ending for our story. Nonetheless, both stories demonstrate a separation from the source language. In the story of Babel, people fell from the tower and scattered on the earth and that caused the creation of various languages. In the story of human perfection, becoming knowledgeable and sophisticated are the reasons people scattered on the earth and create different languages. Although the reasons of this separation, as is mentioned, is quite different, but the result is similar, the indeterminacy of languages. A significant point regarding these two stories is the point of start and end. Though Benjamin's story starts in absolute abstraction, it ends in reality and deals with real languages at the end.

The ideas of 'intended object' and 'mode of intention' are not really strange and they have been discussed throughout centuries as was mentioned before in the present paper. But with a little change in attitude, though indirectly, one can relate Benjamin's debate on this notion to the idea of equivalence. Benjamin states that source and target languages' 'modes of intentions' cannot be equal to each other. We can conclude, from his debate, that equivalence, as in the sense of equal values, does not exist. Yet, the inception of equivalence and the dream for equal values raised in late 1950s and dominated the history of translation for many years (Vinay and Derbelnet, 1958/1995; Nida, 1964; Koller, 1979/1989; Newmark, 1981) only to understand that the very idea of equivalence is just an 'illusion of symmetry between languages' (Snell-Hornby, 1988).

Benjamin's emphasis on history and the task of the translator to communicate in translation the values given to the ST throughout history can be seen as translation identity, a sense of having a past and belonging to something, just like the identity that every work of authorship carries. In the line of authorship, when a work is read, the readers know where the ideas come from and what the underlying historical, cultural, social, political, and economic contexts are. These factors give an identity to the authorial work in the literature. Benjamin wants the same for the product of translation. In fact, in his view, translation is a threshold for the target readers to pass through to get themselves familiar with all the values assigned to the ST. If the translator achieves this task, then translation identity will be formed, like that of the authorial work. But what if the translator fails? Then the product, which cannot be entitled as translation, will be read and understood in terms of target contexts, values, and histories. Does that product have any identity? Should we call it a translation or authorial work? Or perhaps it is nothing but a bastard with no identity.

Closely related to the idea of translation identity is the tool by which it can be created. Benjamin believes that the ST historical values can be communicated through literalism. But why literalism and why not naturalism? Let us first address the second part of the question: why not naturalism? As is previously discussed, naturalism can produce a product without identity, for it first and foremost aims at equivalence - in the sense of equal value between ST and TT. Equivalence dissolves in whatever way possible the ST in target language, thus making translation a two-dimensional phenomenon, a kind in which we start from source language and end in target language, just like Viney and Darbelnet and their journey from Canada to France. Therefore naturalism, which is incapable of communicating the historical values of the ST, does not suit Benjamin's purpose.

Venuti (2010) bemoans the domesticating technique common in Anglo-American translation tradition and by quoting Ronald Barthes - 'a metalanguage is always terrorist' (trans. Richard Howard) - in the very beginning of his paper creates an analogy through which one can easily associate this 'terrorism' to English language. Just like Benjamin, Venuti also talks about 'the violation of translation'; with a little change in perspective, this violation can be created through the translator's inability in communicating the historical values of the ST which leads to a bastard product.

Venuti also touches upon the very notion of 'fluency' created by naturalism and condemns it as a 'discursive strategy [...] capable not only of executing the ethnocentric violence of domestication, but also of concealing this violence by producing the illusionistic effect of transparency' (ibid: 73). Perhaps this 'illusionistic effect of transparency' is no different from our bastard product, for both of them trick the target recipients into believing something as native and ignoring its very foreign nature. Omid Mehregan (2008), in his book entitled 'The Divinity of Translation: Walter Benjamin and the Task of the Translator' (my translation), urges Iranian translators to render foreign languages as foreign, using Benjamin's method of translation. Khaza'ee Far (2008) criticizes Mehregan based on the popularity of the Anglo-American domesticating tradition, but he failed to notice that this domesticating strategy is nothing but a tool to create terrorism in translation, terrorizes the foreign nature of all languages, waging war among them, and finally draws a distinct line between them, indicating that they can never mingle with each other in peace. Perhaps scholars like Benjamin, Venuti and Mehregan dream of a day on which the Israeli Hebrew and the Arab Arabic, or the Iranian Persian and the American English can co-live in absolute peace.

Benjamin considers translation a three-dimensional subject: the first dimension is ST, the second one is target language, and the third one is the language of translation. Hence, he needs a technique that allows the source and target language to coexist with each other and make something new and more complete, thought awkward and difficult to understand. Why awkward, why difficult to understand? An elementary English learner may find English difficult to understand, and sometimes feel awkward when speaking the language with lousy pronunciations and grammatical mistakes. The same reasoning can be applied here. To the readers, this new language, which uses target language lexicon and source language syntax, is awkward and difficult since they are not familiar with its very nature. 
Pym (2014) explains why literalism is preferred by scholars like Benjamin and hence answers the first part of our question: why literalism? First, Pym tries to justify indeterminism in translation from the 'epistemological skepticism' point of view and by referring to Willard Van Orman Quine, the fact that 'different translators will produce different translations'. (Pym, 2014: 89). Then he moves on to explain what is termed as 'observer event' and that 'the accident never fully determines the observations'. The same can be applied to translation with the ST stands for the accident and the translation for observation. Pym states that 'no source text fully determines a translation of that text, if only because translations rely on observations and interpretations' (2014: 89). Benjamin rejects naturalism since it is highly based on observations and interpretations. In Benjamin's attitude, a translation must be fully determined by the ST in order to create the pure language. Of course this absolute determinism is impossible but through literalism higher levels of determinacy is possible and thus favored by Benjamin.

There is one more piece that completes Benjamin's definition of translation and it is the notorious question whether translation is art or science. Though addressing here as the last factor, Benjamin begins The Translator's Task by introducing translation as an art and therefore concludes that its prime purpose is not to communicate the inferior message, for the elevated artistic translational activity cares first about the reconciliation it seeks between the source and the target. Indeed, in Benjamin's outlook, the task of translator is to bring the two languages together, to make the target recipients fully appreciate the fact that they are not alone in this world. The task of the translator is to eradicate the inception of chauvinism by indicating that outside one's borders, customs, histories, language, politics, and cultures, there exists the source. And indeed the task of the translator is to remind us a very simple fact that bonds us perhaps mostly in the times of despair, that though different, we are first and foremost humans and humanity is the foundation based on which the divinity marked our creation. One might argue against the artistic nature of translation, considering it as a science or whatever else. Benjamin presupposes translation as an art with no reasoning. Let us honor Benjamin's contribution to the field and only say that one needs to take a leap of faith, for no one can definitely prove this subject right or wrong and perhaps this is the reason it is notorious.

Let us put all these pieces of information all together and recreates The Translator's Task as a theory for translational activity: a quality translation is the one that is fully determined by the ST. The art of translation endeavors to do so by releasing the pure language through literalism, and syntax is a touchstone based on which the degree to this literalism is determined. Figure 1 illustrates the areas in which Benjamin's translation theory works.

\begin{tabular}{lllr}
\multicolumn{2}{c}{ Determined Pure Language } & \multicolumn{2}{c}{ Undetermined Illusionistic Product } \\
Literalism & Naturalism & Eadical Domestication \\
Interlinear Translation & Literal Translation & Presenting ST with target values & No trace of ST
\end{tabular}

Figure 1. The areas of Benjamin's Translation theory

As is shown in the diagram and also indicated by Benjamin, the best way to release the pure language is to use interlinear translation with target language lexicon and source language syntax. This technique will certainly produce an awkward language, the pure language or the language of translation, which cannot be easily read but as John Sturrock puts, this language's 'abnormalities being so designed as to acknowledge the derivative nature of what we are reading' (2010: 63). A literal translation using target language syntax and lexicon can also be used to release pure language but it must be noted that as one moves from the left side of the diagram to the right side, the level of determinacy decreases to a point that the language of translation becomes absolutely undetermined and reflects no trace of ST, hence suffers from a lack of identity, a product that can designate itself as neither authorial nor translational.

\section{Method}

In order to be able to investigate The Translator's Task's applications and merits in the field, the present paper attempted to produce a four-stage model to release the pure language as intended by Benjamin. Figure 2 depicts this model, which emphasizes on source language syntax and identifying different grammatical categories in a given sentence. In the second stage, the translator should identify the smallest possible unit of translation, which is usually a word or phrase. Syntactical alteration within each unit of translation is allowed. For instance, a noun phrase in English may consist of an article, an adjective, and a head noun. However, this order can be altered when translating into Persian and render the head noun first and the adjective after that. This alteration within each unit of translation is mainly done to prevent ambiguities and obscurities. Yet, the syntactical position of each unit of translation cannot be change and should precisely follow that of the source language. In stage three, as long as denotative meaning makes sense in the context and does not produce a non-sense translation, connotative meanings should be avoided to reduce the degree of interpretation. This does not mean that members of a collocation should be translated literally. Each collocation can be considered as a unit of translation and can be assigned a target language rendering holistically. In terms of expressions and old sayings, as long as the literal translation communicates in the target language without obscurities, other possible renderings should be avoided. Minor additions of determiners and similar grammatical word are recommended in order to help prevent obscurities. Such additions should be put in brackets and indicated to the target readers that they are additions by the translator. 


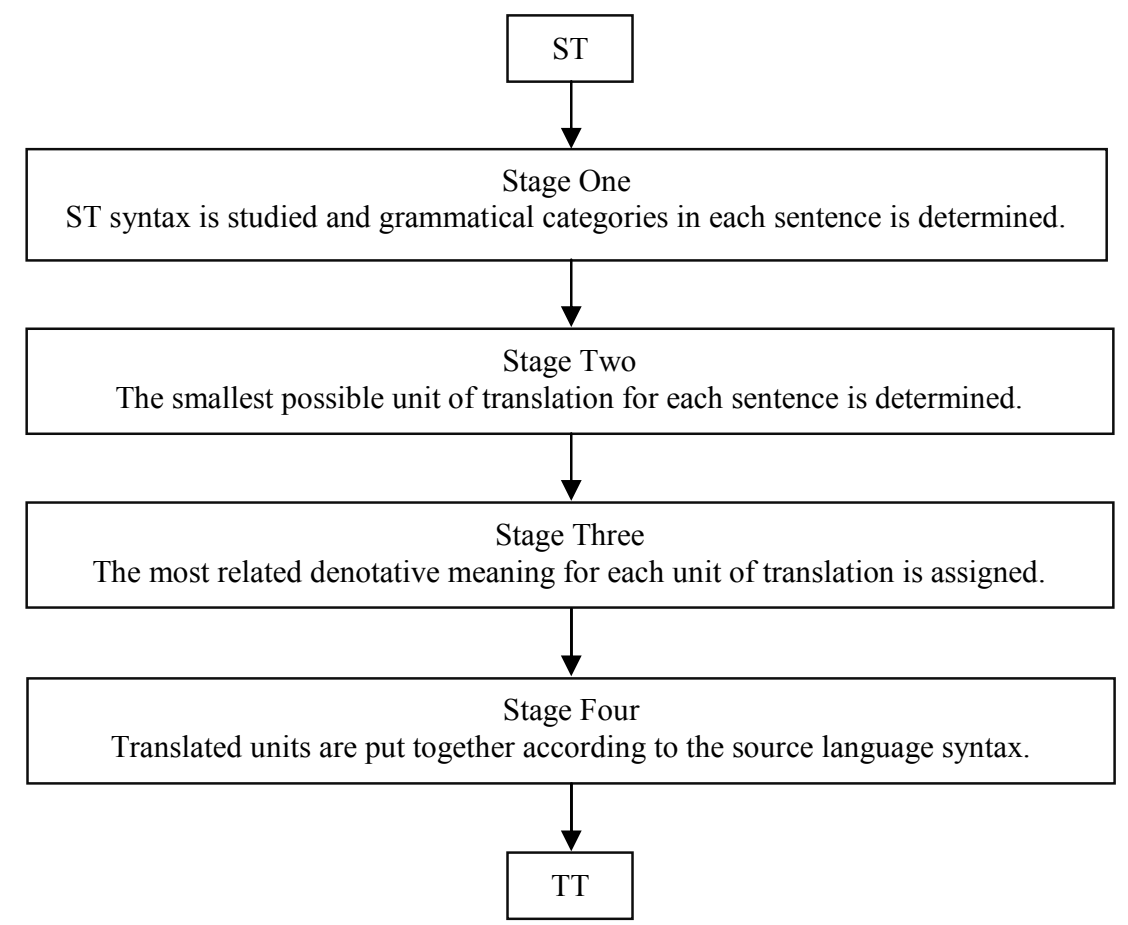

Figure 2. A four-stage translation model based on The Translator's Task

In order to produce a sample translation based on the presented model into Persian, the short story 'The Emperor' by the post-modernist author, Donald Barthelme was chosen (Note 1). The produced translation is referred to as TT1 (Note 2). The same story was also translated into Persian by the Iranian translator, Mazdak Bolouri, and published by Nashr-e Nei in Iran. This Translation is referred to as TT2 (Note 3). The two TTs were studied through a back-translation bottom-up analysis in order to examine their levels of determinacy by the ST. To do so, each Persian rendering of the smallest unit of translation was back-translated into English and later categorized as $D$ or $U$. Category $D$ stands for determined, which refers to all the renderings that were highly determined by their respective ST unit of translation. Category $U$ stands for undetermined, which refers to all the rendering that were interpreted by the translator and therefore determined by the translator. For the purpose of the present paper, each $D$ category was evaluated positively and each $U$ category negatively. Finally, a statement of translation quality in terms of determinacy by the ST was made for each TT.

\section{Results and Discussion}

One of the prime purposes of the present paper is to provide a practical example manifesting the release of pure language in Benjamin's point of view and then compare this translation with an actual published one. To do so, the short story 'The Emperor' was chosen and the first paragraph of TT1 and TT2 were studied in vivid details. The analysis revealed that TT1 enjoys higher levels of determinacy by the ST than TT2. Table 1 summarizes key units of translation, their renderings in TT2 and their back-translation into English.

Table 1. TT2 analysis

\begin{tabular}{|c|c|c|c|c|}
\hline No. & ST unit of translation & $\begin{array}{l}\text { TT2 rendering for the } \\
\text { given unit }\end{array}$ & $\begin{array}{l}\text { Back translation of the } \\
\text { given unit }\end{array}$ & Category \\
\hline 1 & each morning & هر روز صبح & each morning day & $\mathrm{U}$ \\
\hline 2 & the emperor & امجِراتور & the emperor & $\mathrm{D}$ \\
\hline 3 & weigh & بررسى مى كند & check & $\mathrm{U}$ \\
\hline 4 & each evening & هر روز عصر & each evening day & $\mathrm{U}$ \\
\hline 5 & will not rest & آرام نمى كيرد & does not calm down & $\mathrm{U}$ \\
\hline 6 & a certain weight & بار مسئوليت مشخصى & $\begin{array}{l}\text { a certain burden of } \\
\text { responsibility }\end{array}$ & $\mathrm{U}$ \\
\hline 7 & has passed & احساس نكند & does not feel & $\mathrm{U}$ \\
\hline 8 & through his hand & در دستانش & in his hands & $\mathrm{U}$ \\
\hline 9 & has declared & اعلام كرده است & has declared & $\mathrm{D}$ \\
\hline 10 & the paramount number & عدد بسيار مهم & the most important number & $\mathrm{D}$ \\
\hline 11 & his reign & سلطنت او & his reign & $\mathrm{D}$ \\
\hline 12 & the paramount color & رنگ برنز & the superior color & $\mathrm{U}$ \\
\hline 13 & from palace to palace & از قصرى به قصر & $\begin{array}{l}\text { from palace to another } \\
\text { palace }\end{array}$ & $\mathrm{D}$ \\
\hline
\end{tabular}


14 along the underground corridors

\begin{tabular}{cc}
15 & gorgeous wall hangings \\
16 & beautiful ladies \\
17 & how many more \\
18 & responsible officials \\
19 & must be strangled \\
20 & his will prevails, \\
& absolutely \\
\hline
\end{tabular}

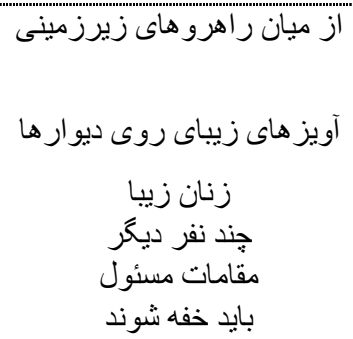

through the underground

corridors

gorgeous hangings on the walls

beautiful ladies

how many other people

responsible officials

must be strangled
D

D

D

D

D

his will absolutely prevails D

As can be seen, the way the words 'weigh', 'weight' and 'rest' are treated reflects the degree to which naturalism deals with interpretation rather than translation. The word 'weigh' is translated "بررسى كردن"which means 'to check' in English. Surprisingly, the word 'weight' is rendered "بار مسئوليت"which is an equivalent for 'a burden of responsibility'. It is obvious that the original writer has some purpose for using the verb 'weigh' and its noun 'weight' and wants the readers to come to an understanding about 'the emperor' who 'weighs the documents'. Whatever this understanding is, it is the responsibility of the readers to come to. The same way of rendering is applied to the word 'rest' which is translated "آرام كرفتن", a Persian word for 'to calm down'. Although the word 'paramount' has been used two times with the same meaning in the original text, this word is first translated 'the most important' and in another place 'the superior'. The reason not to repeat this word just like the original is not clear. Perhaps, this is due to 'ennoblement', a phenomenon Anthony Berman (1985/2012) calls a 'negative analytic' on the part of the translators to 'improve on the original'.

As is obvious in the back translation of each unit, what is really communicated in most cases can be considered as one of many possible interpretations which is inferred by the translator. No one can be absolutely sure that the original writer meant 'to check' or 'the burden of responsibility' by the words 'weigh' and 'weight'. This translation also reveals the reductionist nature of domesticating technique. Reductionist in a sense that the target reader has to accept the translator's interpretation and does not have the liberty, like that of the original reader, to decide for themselves what the original writer means by the word 'weigh' or similar ones. Hence, naturalism aims at interpretation and restricts target recipients freedom in interpretation by feeding them the translator's interpretation. This is done through creating a facade, an illusion of fluency and beauty.

Table 2 summarizes key units of translation, their renderings in TT1 and their back-translation into English. As can be seen, the translated text enjoys higher levels of determinacy by the ST. In this translation, the task of interpretation is left to the target readers. The translated text follows precisely the source language syntax and renders each unit of translation meaningfully and denotatively in their respective context. Although the kind of language that the target readers are exposed to is strange, it helps the readers to enter the world of the ST and to understand its differences and similarities with their own context.

Table 2. TT1 analysis

\begin{tabular}{|c|c|c|c|c|}
\hline No. & ST unit of translation & $\begin{array}{l}\text { TT2 rendering for the } \\
\text { given unit }\end{array}$ & $\begin{array}{l}\text { Back translation of the } \\
\text { given unit }\end{array}$ & Category \\
\hline 1 & each morning & هر صبح & each morning & $\mathrm{D}$ \\
\hline 2 & the emperor & امبر اتور & the emperor & $\mathrm{D}$ \\
\hline 3 & weigh & وزن مى كند & weigh & $\mathrm{D}$ \\
\hline 4 & each evening & هر عصر & each evening & $\mathrm{D}$ \\
\hline 5 & will not rest & استر احت نخو اهد كرد & will not rest & $\mathrm{D}$ \\
\hline 6 & a certain weight & وزن خاصى & a certain weight & $\mathrm{D}$ \\
\hline 7 & has passed & عبور كند & passes & $\mathrm{D}$ \\
\hline 8 & through his hand & از ميان دستش & through his hand & $\mathrm{D}$ \\
\hline 9 & has declared & اعلام كرده است & has declared & $\mathrm{D}$ \\
\hline 10 & the paramount number & عددٍ عالى & the paramount number & $\mathrm{D}$ \\
\hline 11 & his reign & سلطنتش & his reign & $\mathrm{D}$ \\
\hline 12 & the paramount color & رنعَ عالى & the paramount color & $\mathrm{D}$ \\
\hline 13 & from palace to palace & از قصر به قصر & from palace to palace & $\mathrm{D}$ \\
\hline 14 & $\begin{array}{l}\text { along the underground } \\
\text { corridors }\end{array}$ & در راستاى دالانهاى زيرزمينى & $\begin{array}{l}\text { along the underground } \\
\text { corridors }\end{array}$ & $\mathrm{D}$ \\
\hline 15 & gorgeous wall hangings & آويز هاى ديوارى زيبا & gorgeous wall hangings & $\mathrm{D}$ \\
\hline 16 & beautiful ladies & خانم هاى زيبا & beautiful ladies & $\mathrm{D}$ \\
\hline 17 & how many more & جه تعداد بيشتر & how many more & $\mathrm{D}$ \\
\hline 18 & responsible officials & مقامات مسئول & responsible officials & $\mathrm{D}$ \\
\hline 19 & must be strangled & بايد خفه شوند & must be strangled & $\mathrm{D}$ \\
\hline 20 & $\begin{array}{l}\text { his will prevails, } \\
\text { absolutely }\end{array}$ & ار اده اش غالب شود، كاملاً & his will prevails, absolutely & $\mathrm{D}$ \\
\hline
\end{tabular}




\section{Conclusion}

The present paper attempted to provide a clear explanation on The Translator's Task through investigating the rationale behind this work. It further provided a translation model based on the theory and produced a sample translation. The sample translation was compared with a published version and the quality of each translation was investigated in terms of the levels of determinacy by the ST. It was concluded that the translation produced by the model based on The Translator's Task enjoyed a better quality in terms of the levels of determinacy by the ST. The remaining issue needs addressing is the application of The Translator's Task and any models based on this theory. The matter calls for further investigation in the field. One area which can be studied is the translation of poetry based on The Translator's Task. As a final remark, the researcher would like to indicate the fact that the presented model based on The Translator's Task by no mean produces a better translation over any other possible translation models. It has to be stated that this model can be used if it suits the purpose of translation, the ST, or the target culture in which the ST is being translated.

\section{Reference}

Barthelme, D. \& Gates, D. (2005). Sixty stories, London: Penguin Books.

Barthelme, D. (2009). Robert Kennedy saved from drowning, trans. M. Bolouri, Tehran: Nashr-e Nei.

Benjamin, W. (1923/2012). The translator's task, trans. S. Rendall. In L. Venuti (Ed.), The translation studies reader ( ${ }^{\text {rd }}$ ed.), (pp. 75-83), New York: Routledge.

Berman, A. (1985/2012). Translation and the trials of the foreign, trans. L. Venuti. In L. Venuti (Ed.), The translation studies reader ( ${ }^{\text {rd }}$ ed.), (pp. 240-253), New York: Routledge.

Derrida, J. (1999/2012). What is a 'relevant' translation? trans. L. Venuti. In L. Venuti (Ed.), The translation studies reader ( $3^{\text {rd }}$ ed.), (pp. 365-388), New York: Routledge.

Khaza'ee Far, A. (2008). Linguistic radicalism in translation in Iran. Naame Farhangestan, 38, 44-54.

Koller, W. (1979/1989). Equivalence in translation theory, trans. A. Chesterman. In A. Chesterman (Ed.), Readings in translation theory, Helsinki: Finn Lectura.

Mehregan, O. (2008). The divinity of translation: Walter Benjamin and the task of the translator, Tehran: Farhang-e Saba.

Newmark, P. (1981). Approaches to translation, Oxford: Pergamon.

Newmark, P. (2009). The linguistic and communicative stages in translation theory. In J. Munday (Ed.), The Routledge companion to translation studies, (pp. 20-35), New York: Routledge.

Nida, E. A. (1964). Toward a science of translating, Leiden: E. J. Brill.

Pym, A. (2014). Exploring translation theories ( ${ }^{\text {nd }}$ ed.), New York: Routledge.

Sanders, J. (2003). Divine words, cramped actions: Walter Benjamin — an unlikely icon in translation studies. TTR, 16(1), 161-183.

Saussure, F. de (1916/1974). Course in general linguistics, trans. W. Baskin, Glasgow: Fontana Collins.

Schleiermacher, F. (1813/2012). On the different methods of translating, trans. S. Bernofsky. In L. Venuti (Ed.), The translation studies reader ( $3^{\text {rd }}$ ed.), (pp. 43-63), New York: Routledge.

Seleskovitch, D. \& Lederer, M. (1984). Interpreter pour traduire, Paris: Didier.

Snell-Hornby, M. (1988). Translation studies: an integrated approach, Philadelphia: Benjamins.

Steiner, G. (1975). After Babel: aspects of language and translation, London: Oxford University Press.

Sturrock, J. (2010). Writing between the lines: the language of translation. In M. Baker (Ed.), Critical readings in translation studies, (pp. 49-64), New York: Routledge.

Venuti, L. (1995). The translator's invisibility, New York: Routledge.

Venuti, L. (2010). Translation as cultural politics: regimes of domestication in English. In M. Baker (Ed.), Critical readings in translation studies, (pp. 65-79), New York: Routledge.

Viney, J. P. \& Darbelnet, J. (1958/1995). Comparative stylistics of French and English: a methodology for translation, trans. \& ed. J. Sager \& M. Hamel, Philadelphia: Benjamins.

Yule, G. (2014). The study of language (5 ${ }^{\text {th }}$ ed.), Cambridge: Cambridge University Press.

\section{Notes}

Note 1. ST

Each morning the emperor weighs the documents brought to him, each evening he weighs them again; he will not rest until a certain weight has passed through his hand; he has declared six to be the paramount number of his reign, black the paramount color; he hurries from palace to palace, along the underground corridors, ignoring gorgeous wall hangings, bells, drums, beautiful ladies; how many more responsible officials must be strangled before his will prevails, absolutely? (Barthelme \& Gates, 2005: 424) 
Note 2. TT1

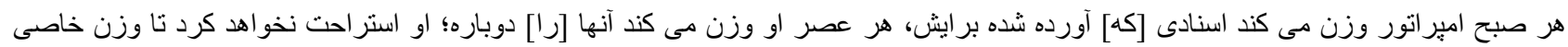

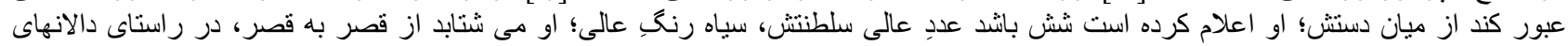

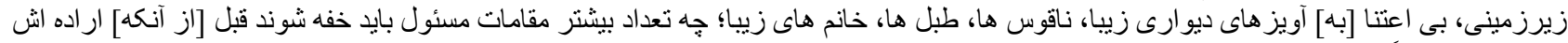

Note 3. TT2

غالب شود، كاملاً؟

هر روز صبح امبرانور اسنادى را كه برايش آورده اند بررسى مى كند، هر روز إنى عصر دوباره آنها را بررسى ميى كند؛ تا وقتى كه بار مسئوليت

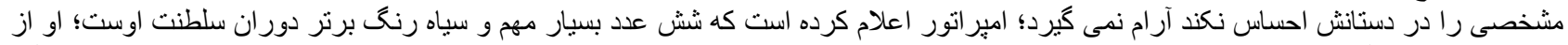

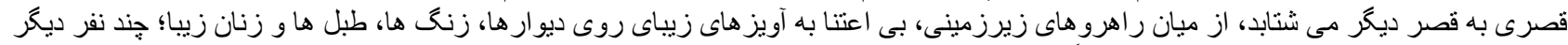

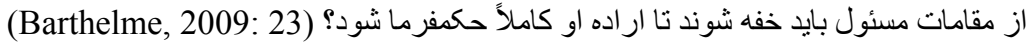

